\title{
Thyroid Abscess Due To Brucellosis: Case Report
}

\author{
Bruselloza Bağh Tiroid Apsesi: Olgu Sunumu \\ Rezan HARMAN ${ }^{1}$, Zahide AŞIK ${ }^{1}$, Dilara İNAN ${ }^{1}$, Özge TURHAN ${ }^{1}$, Betil Özhak BAYSAN ${ }^{2}$, Filiz GÜNSEREN ${ }^{1}$ \\ ${ }^{1}$ Akdeniz Üniversitesi Tip Fakültesi, İnfeksiyon Hastalkları ve Klinik Mikrobiyoloji Anabilim Dall, \\ ${ }^{2}$ Tibbi Mikrobiyoloji Anabilim Dal, Antalya
}

Submitted / Başvuru tarihi: 04.11.2008 Accepted / Kabul tarihi: 29.12.2008

Brucellosis is primarily seen in endemic regions and is also common worldwide. The range of clinical features of brucellosis is wide. According to our knowledge, a thyroid abscess caused by Brucella spp. has not previously been reported in Turkey. In this study, we reported a 20 year old man who had a thyroid abscess caused by Brucella spp.

Key words: Brucellosis; Brucella spp.; thyroid abscess.
Bruselloz başta endemik bölgelerde olmak üzere tüm dünyada yaygın görülen bir zoonozdur. Brusellozun klinik bulguları çeşitlilik gösterebilir. Bilgimiz dâhilinde Türkiye' de daha önce Brucella spp.' nin etken olduğu tiroid apsesi bildirilmemiştir. Bu çalışmada Brucella spp.' nin etken olduğu tiroid apsesi olan yirmi yaşında bir erkek hasta sunulmuştur

Anahtar sözcükler: Bruselloz; Brucella spp.; tiroid apsesi.

\section{INTRODUCTION}

As a zoonotic disease, brucellosis is commonly seen all around the world and is notably endemic in Mediterranean Countries, Central and South America. ${ }^{[1]}$ Brucella spp. are small, gram-negative coccobacilli which are immobile and sporeless. ${ }^{[2]}$ The Brucella species are usually oxidase positive, catalase-positive and reduce nitrates to nitrites. Although they grow at aerobic conditions, many strains require an atmosphere containing $5-10 \%$ added $\mathrm{CO}_{2}$ when first isolation is performed for growth. ${ }^{[3]}$

Brucella melitensis and Brucella abortus are the species mostly known to cause disease in humans. Brucella spp. is primarily transmitted to humans by ingestion, skin contact through fissures-scratches and inhalation of contaminated dusts. Brucellosis may present as an acute, subacute and/or chronic disease in humans. The symptoms include fever, headache, arthralgia, back pain, cough, sweating, myalgia, anorexia, fatigue and loss of weight. ${ }^{[1,4]}$ It is a systemic disease, and may affect the gastrointestinal system, hematologic system, muscle and skeletal systems, genitourinary system, neurological system, respiratory system, cardiovascular system, eye and skin. ${ }^{[3]}$

To our best knowledge, our case is the first case report of a thyroid abscess caused by Brucella spp. in Turkey.

\section{CASE REPORT}

This report describes a twenty year old male, admitted to the physician six weeks earlier with back pain and subsequent left hip and left leg pains. He was treated with an analgesic and muscle relaxant but the therapy failed to reduce the symptoms. Two weeks later he went to the physician again. After the brucella standard tube agglutination test showed positivity at 1/160 titers, he was referred to our clinic for further evaluation and testing. The three phase-bone scintigraphy was performed and showed an increased diffuse activity at all phases on the left sacroiliac joint that demonstrated left sacroileitis.

In his medical history, he informed us about the consumption of raw cheese and had an unremarkable family history. On physical examination, limited joint mobility and mobility aggravated pain in the left hip were detected. A complete blood count, blood biochemis-

XIII. Türk Klinik Mikrobiyoloji ve Infeksiyon Hastalıkları Kongresi'nde (14-18 Mart 2007, Belek-Antalya) poster olarak sunulmuştur.

Correspondence (IIletişim adresi): Dr. Özge Turhan. Akdeniz Üniversitesi Tıp Fakültesi, İnfeksiyon Hastalıkları ve Klinik Mikrobiyoloji Anabilim Dalı, Antalya, Turkey. Tel: 02422496716 e-mail (e-posta): ozgeturhan@akdeniz.edu.tr

(c) Trakya Üniversitesi Tıp Fakültesi Dergisi. AVES Yayıncılık tarafından basılmıştır. Her hakkı sakııdır.

(๑) Medical Journal of Trakya University. Published by AVES Publishing. All rights reserved. 
try, liver function tests, sedimentation rate and C-reactive protein measurement were performed. The results were: Haemoglobin $14.2 \mathrm{~g} / \mathrm{dL}$; white blood cell (WBC) at 8300 $\mathrm{mm}^{3}$ (51\% neutrophil, 36\% lymphocyte, $12 \%$ monocyte), thrombocyte at $304.000 \mathrm{~mm}^{3}$, aspartate aminotransferase (AST) at $31 \mathrm{U} / \mathrm{L}$, alanine aminotransferase (ALT) at 94 $\mathrm{U} / \mathrm{L}$, erythrocyte sedimentation rate (ESR) at $44 \mathrm{~mm} / \mathrm{h}$ and C-reactive protein (CRP) at $11 \mathrm{mg} / \mathrm{dl}$. Diagnosis of brucella sacroileitis was confirmed and the therapy regimen of rifampicine 1x600 $\mathrm{mg}$ /day and doxycycline 2x100 mg/day was planned. Five days later, the patient reported the pain in his neck. Neck ultrasonography revealed hyperechogenic septations involving the right thyroid lobule, compatible with an abscess or nodule and the dimensions were $28 \times 22 \times 22 \mathrm{~mm}$. We also determined a few milimetric reactive lymph nodes on neck. Then the patient was hospitalized in the Infectious Disease and Clinical Microbiology Department subsequent to obtaining specimens by needle aspiration biopsy. Specimens for culture of purulent drainage in blood culture media. Furthermore, one blood culture vial from the patient was obtained. Brucella spp. was isolated from pus and blood cultures with the BACTEC 9240 blood culture system (Becton Dickinson, U.K). The patient was discharged due to normal thyroid fuction tests, but an outpatient clinic follow-up was planned within the same therapy regimen. During the follow-up, he had no problems and his laboratory findings were all within the normal range. The brucellosis therapy was extended to 11 weeks, until the outcome in patients was lost to follow up.

\section{CONCLUSION}

Brucellosis is a systemic infectious disease and may also affect many organs and systems. The most common complication is bone and joint involvement in brucellosis,which is reported in $20-85 \%$ of different cases. The most frequent form is sacroileitis and the second one is peripheral arthritis especially involving the knee and hip joints. ${ }^{[1,5]}$

Subacute thyroiditis is rarely seen as a complication of brucellosis. ${ }^{[6]}$ Acute/subacute suppurative thyroiditis leading to a thyroid abscess is a rare clinical entity, representing less than $1 \%$ of all brucella complications and $0.1 \%$ to $0.7 \%$ of all surgically treated thyroid diseases. ${ }^{[7,8]}$ Hendrick et al. ${ }^{[9]}$ reported that $28(24 \%)$ of 117 patients had acute thyroiditis and only 6 patients (5\%) had thyroid abscess. Thyroid abscess is uncommon because of the gland status, such as anatomic position, its capsulated nature, iodine-rich environment, bilateral blood flow, anastomosing superior and inferior arteries with extensive lymphatic drainage that provide protection against bacterial invasion and growth. Fine needle aspiration biopsy is used for diagnosis of thyroid abscess and computerized tomography is suggested for evaluation of congenital anomalies in recurrent cases. Gram-positive bacteria (Staphylococcus aureus and Streptococcus spp.) are the most commonly responsible agents, however, gram-negatives are rarely recognized. Such organisms as Klebsiella spp., Salmonella typhii, Salmonella bradenburg, Eikinella corrodenss,
Acinetobacter calcoaceticus are reported as rare causative agents of thyroid abscess in the literature. ${ }^{[10,11]}$

Starakis et al. ${ }^{[7]}$ report a case of an 87-year-old woman who presented with acute thyroiditis and eventually developed a thyroid abscess caused by Brucella melitensis in Greece. Rifampicin (600 mg/d) and doxycycline (200 $\mathrm{mg} / \mathrm{d}$ ) were prescribed for 3 months, and doxycycline alone was administered for 6 more months in this study. In addition, she was operated on and the right thyroid lobe and isthmus were removed. Thyroid abscess is more frequent in children than adults. However, Menegaux et al. ${ }^{[12]}$ reported five thyroid abscess case reports, 4 of them in adults. In our adult patient, we isolated Brucella spp. in a sample obtained from drainage of the thyroid abscess.

In conclusion, any organ system can be involved in brucellosis. Especially in endemic areas, atypical forms of the disease must be considered in the differential diagnosis. The case described in this article is unique in that it is the first reported case of thyroid abscess caused by Brucella spp. in our country.

\section{Conflict of Interest}

No conflict of interest declared by the authors.

\section{REFERENCES}

1. Solera J, Martinez- Alfaro E, Espinosa A. Recognition and optimum treatment of brucellosis. Drugs 1997;53:245-56.

2. Young EJ. Brucella Species. In: Mandell GL, Bennett JE, Dolin R, editors. Principles and Practice of Infectious Diseases. 6th ed. Philadelphia: Churchill Livingstone; 2005;2669-74.

3. Shapiro DS, Wong JD. Brucella. In: Murrey PR, Baron EJ, Pfaller MA, Tenover FC, Yolken RH, editors. Manuel of Clinical Microbiology. 7th ed.Washington: American Society for Microbiology; 1999;625-31.

4. Aydin G, Tosun A, Keles I, Ayaslioglu E, Tosun O, Orkun S. Brucellar spondylodiscitis: a case report. Int J Clin Pract 2006;60:1502-5.

5. Çelen MK. Komplike Bruselloz. ANKEM Dergisi 2006;20:214-8.

6. Sirmatel F, Akarsu E. Case report: A brucellosis case with subacute thyroiditis. Mikrobiyoloji Bült. 2004;38:149-53.

7. Starakis I, Stoubou V, Siagris D, et al. Brucellar thyroid abscess: Case report and review of the causes and management of this rare medical entity. Infect Dis Clin Pract 2007;15:70-3.

8. http://emedicine.medscape.com/article/962194-overview (29.12.2008)

9. Hendrick JW. Diagnosis and treatment of thyroiditis. Ann Surg 1956;144:176-87.

10. Jacobs A, Gros DAC, Gradon DJ. Tyroid abscess due to Acinetobacter calcoaceticus: Case report and review of the causes of and current management strategies for thyroid abscesses. South Med J 2003;96:300-7.

11. Rohondia OS, Koti RS, Majumdar PP, Vijaykumar T, Bapat RD. Thyroid abscess. J Postgrad Med 1995;41:52-4.

12. Menegaux F, Biro G, Schatz C, Chigot JP. Thyroid abcess, Apropos of 5 cases. Ann Med Intern 1991;142:99-102. 